\title{
The Influence of Communication ApPrehension on the Process OF LEARNING A FOREIGN LANGUAGE
}

\author{
Kateřina Smejkalová $^{1}$; Josef Smejkal ${ }^{2}$; Kateřina Juráčková ${ }^{3}$ \\ Jan Evangelista Purkyně University in Ústí nad Labem, \\ Faculty of Social and Economic Studies, \\ ${ }^{1,2}$ Department of Foreign Languages, \\ ${ }^{3}$ Department of Management, \\ Moskevská 4, 40096 Ústí nad Labem, Czech Republic \\ e-mail: ${ }^{1}$ katerina.smejkalova@ @jep.cz; ${ }^{2}$ josef-smejkal@ centrum.cz; \\ k3atka.jurackova@gmail.com
}

\begin{abstract}
The aim of this study is to explain the term "communication apprehension" that has not yet been precisely defined in Czech professional literature. After the appropriate terminology is defined, in its first part the article focuses on the analysis of the communication barrier perceived by students. In relation with this analysis and on the base of teachers' experience showing that students take a rather passive approach to learning foreign languages, in its empirical part, the authors of the article concentrate on the question whether the level of communication apprehension experienced by individuals when communicating in their mother tongue may influence their learning a foreign language.
\end{abstract}

\section{Keywords}

Communication apprehension; Foreign language; Communication apprehension in mother tongue; Learning a foreign language.

\section{Introduction}

At universities, the main objective of learning foreign languages in non-philological fields of study is to facilitate students' achieving communication competence and self-directed autonomous learning. In addition to learning a foreign language, students should be able to develop their thinking and master appropriate skills and habits. It is also very important to transform passive student behaviour into more active use of a particular language. It is not uncommon that some students have a fear of using a foreign language in real conversations which is one of the main reasons why the teacher should be familiar with the students' confidence in communication, not just in a foreign language but also in their native language communication.

\section{The Term "Communication Apprehension"}

First, let's focus on communication apprehension from a general point of view and then move on to the communication apprehension in foreign languages. This term lacks a single accepted definition since the same term, with slight modifications, may also be expressed by the following terms: communication apprehension [23], communication barrier or barriers [14], [24], language barriers, or communication anxiety, in many foreign studies e.g. [19].

According to Průcha [23], communication apprehension is a cause of great inter-individual differences in communication activities of students. Apprehension in tuition sometimes reaches even pathological levels when some students are so ashamed of speaking in front of 
the whole class that they do not join verbal communication even if they know the right answer.

A pedagogical dictionary [24] uses the term "communication barrier" and explains it as a barrier of a physical (e.g. due to speaking or hearing disorders) or mental nature (e.g. fear of speaking in public). Křivohlavý in [14] explains the term "communication barriers" as everything that somehow disrupts the course of communication. Thus he sees it as an external barrier to the transfer of a communication signal.

"However, barriers can be directly in the transmitter or receiver. For example noise that disturbs the teacher's speech, or different motivational orientation of students than of a teacher."

We have to differentiate between the terms "communication apprehension" and "reluctance to communicate" which is a natural, primarily professionally conditioned phenomenon, concerning for example teachers or politicians. It is usually a consequence of particularly cognitive oversaturation and overload by various impulses and it is connected to the effort to relax from all contacts. This reluctance to communicate is usually temporary. Long-term avoidance of interpersonal contacts is a manifestation of mental imbalance. [28, p. 26]

\subsection{Communication Apprehension in Foreign Languages}

Compared to the aforementioned Kr̈ivohlavý's definition of communication barriers [14], Celerová [1] understands the meaning of a "communication barrier" in foreign languages differently. The author divides communication barriers into two groups; in the strict sense there are those formed as a result of incorrect selection and use of linguistic means in speech, and in the broader sense the communication barriers derived from the interdisciplinary approach to solving communication questions and related problems. According to Celerová, communication barriers can be defined as a barrier of a linguistic and non-linguistic nature (division to logical, stylistic, semantic, and phonetic) which is manifested in the speech of communicants and may impede or even prevent communication targets from being achieved.

In connection to overcoming miscellaneous difficulties in foreign language communication, Hendrich [7] similarly speaks about barriers that are of a linguistic and pedagogicalpsychological nature. According to Hendrich, language barriers occurring particularly in adults are related to the insufficiency of linguistic means that a student has at his/her disposal for expressing his/her ideas in a foreign language (so-called Labov's linguistic deficit). This definition corresponds to the term "expression barriers in communication" according to Adams [21, pp. 69-71]. The barriers of a pedagogical-psychological nature "emerge due to apprehension to speak a foreign language, to imitate foreign pronunciation, as well as due to a fear of making mistakes, fear of being ridiculous while speaking a foreign language". This fear or internal apprehension of a foreign language communication may be defined as a feeling of tension, concerns and nervousness that the process of foreign language teaching evokes in a student. Similarly, McCroskey [19] defines communication anxiety by how much an individual feels fear of or anxiety about becoming involved in real or imaginary communication with others.

This paper will be primarily based on the $2^{\text {nd }}$ part of the definition stated in the Pedagogical Dictionary [24] which is, in our opinion, stated under an ambiguous term of communication barrier but which may be applied to foreign language teaching as it is a barrier "emerging in acquiring a foreign language when a speaker cannot manage to use his/her partially developed language knowledge for communication. It has mental causes, most frequently apprehension of the fact that he/she (...) can make linguistic mistakes" [24], [7]. However, this paper will use the term "communication apprehension" for the sake of consistency. 


\subsection{Causes of Communication Apprehension}

The main, hardly influenceable resources of the communication apprehension problem include student's innate character anxiety related to introversion of a character. Communication apprehension probably results from a number of other sources, including strict upbringing and education, lack of communication skills, and imitating others [26], [9]. This is also confirmed by Jelínek in [11] who sees the causes of communication apprehension in a way of communication within family and broader social vicinity. It very much depends on the fact how parents communicate with a little child, what specialized way of expressing they use [27, p. 343]. In connection with this, Jelínek in [11] mentions the so-called concept of two linguistic codes (developed by Bernstein). "A developed (...) code is formed in a child when parents and other family members stimulate a speech activity of the child by their interest and attention and when they happily react to his/her actions. A limited (restricted) linguistic code is formed due to a little interest of parents in child's speech, due to their poor expressing limited only to orders and bans." One of the causes of a higher level of communication apprehension of students may also be reduction of communication among themselves. With better opportunities, development of technologies and primarily an easier access to these advanced technologies, the proportion of impersonal, indirect contact among people in a form of writing increases to the detriment of interpersonal verbal communication.

According to Forster [5], "tacit" behaviour of communication participants is often related to previous frustrating experience. It can mean that the reluctance to undergo a communication risk expresses certain forms of fear of speaking. The cause may be excessive concentration on an "all-wise" teacher who provides students with very little space to their own, self-planned and reliable activity. We should not always seek the cause only in a communication deficit of students but in their little experience with active, self-initiated communication behaviour. This phenomenon may be, as Forster [5] suggests, changed by working in small groups with adequate assignment of tasks.

The research of a communication climate [22] found that the communication climate does not depend on the composition of a class being taught. On the contrary, it is defined by a teacher's own approach and a style of teaching. Based on the given information we can assume that a teacher inclining to the constructivist approach will positively influence the communication climate in terms of helpful atmosphere supporting cooperative education. We suppose that asymmetric, irregular division of verbal activities of students during foreign language education, as researched by Žofková [14], when student's verbal activity represents only $8 \%$ of time from the total tuition, and when students do not have an opportunity to communicate during tuition, leads to apprehension to express themselves, i.e. to communication apprehension and reluctance to communicate.

Communication apprehension may also occur only exceptionally, in a certain situation, and under certain circumstances. It is, for example, anxiety of acceptance, orientation or performance. In connection to the term "communication apprehension" we also have to mention the term "communication status". Researches [23] imply that a teacher as a subject of teaching highly contributes to the formation of groups of students who have a different communication status. Some students have a high communication status, they often communicate with a teacher. Other students, on the other hand, have little or even no involvement and their communication status is really low. An analogous research at Czech schools [23] suggests that the proportion of student's utterance decreases with higher grades of elementary and secondary school $(24 \%-14 \%)$ while the proportion of teacher's utterance increases $(76 \%-86 \%)$. According to Kabardov [10], it is necessary to take into account typological differences of students in communication while acquiring foreign languages. In his opinion, there is on the one hand a communicative type of students characterized by a 
communicative activity and initiative, a large scope of speech production, better hearing memory, and on the other hand a non-communicative type of students with a small scope of speech production, vagueness of communication acts, passivity in foreign language relations, better visual memory.

A significant part of research focused on studying communication apprehension has linked communication to academic performance or school results. For example, it has been proved that students who do not hesitate to communicate during tuition achieve better results in speaking skills than students who highly hesitate to communicate. [2] Therefore, there is significant inverse dependency between communication apprehension and results of education. It applies that "the higher communication apprehension students have, the worse educational results they achieve and on the contrary - students with the lowest communication apprehension have the best educational results" [24]. Furthermore, it was found out that the achieved level of communication apprehension proportionally increased with higher age (the research examined students at elementary and secondary schools). Communication apprehension does not decrease with age but, on the contrary, it increases significantly. The research of McCroskey [18], [19] suggests, for example, that up to $20 \%$ of all adults can experience some of the forms of communication anxiety. Individuals with a high level of communication anxiety typically avoid communication with other people which means that these individuals tend to be perceived negatively when they interact with other people. Based on these results we can assume that communication apprehension will culminate in the population of adult students, which is also a subject of our research.

\subsection{Possibilities to Eliminate Communication Apprehension}

Horwitz [8] indicated a relation between foreign language anxiety and reluctance to verbally interact; they mutually influence each other. Young [29] discovered that students generally become anxious when they have to use a foreign language in front of others. According to Krrivohlavý in [17, p. 17], communication barriers appear "... where distrust or antipathy predominate". Even the research results proved [20] that the willingness of an individual to communicate in a target language is associated with the feeling of well-being, with high selfimage, extroversion, low level of anxiety, and high level of perceived competence, while reluctance to communicate (i.e. communication apprehension) is analogically connected to the opposites, that means discomfort, low self-image, introversion, high level of anxiety, and low level of perceived competence. Reluctance to communicate may appear when a student does not have a sense of belonging to a target language group or he/she feels threatened by the loss of identity of his/her mother tongue. [6], [8] Although professional literature has been promoting the emphasis on target language significance for a long time, a restored interest in the role of mother tongue in foreign language education has occurred quite recently.

Some authors argue that it depends on a possibility and the amount of use of mother tongue within foreign language education. Polio and Duff [4] presented a statement of a German teacher who said that, "... if you want to create a relaxed atmosphere ... it is difficult to create it only in German ..." (that means only in a foreign language). This comment, together with an opinion of many foreign language teachers, supports a concept that in many situations of foreign language education a higher amount of target language use may be accompanied by higher anxiety in lots of students. And on the contrary, the use of mother tongue helps students reduce the affective filter. [13]

For example, Macaro [16, p. 49] stated that the use of mother tongue in foreign language education supports linguistic associations in students and further reduces a limited memory capacity of students. Furthermore, it was found out that the level of foreign language complexity and the usage rate of mother tongue by students are directly proportional. Klapper 
[12] recommends using bilingual education because dogmatic exclusion of mother tongue from target language education may lead to displeasure, frustration, and negative affective factors limiting efficient foreign language education in students. Therefore, it can be assumed that the usage rate of foreign language is also linked to the level of mother tongue competence of students, and also that both languages (their mother tongue and a foreign language) equally influence the level of communication apprehension.

\section{2}

\section{Research}

\subsection{Research Objective}

The aim of our research was to find out to what extent students perceive their own communication apprehension in foreign language classes. And then we were preoccupied with the following scientific question: To which extent the level of communication apprehension in students in their mother tongue is related to their reluctance to communicate in a foreign language?

As a follow-up to research findings stated in a theoretical part of this work, we determined research hypotheses to which we were inspired by the results of some researches, for example [13], [12], [18], [19], [26].

Hypothesis 1: There is a mutual relation (direct proportion) between the level of perceived achieved communication apprehension in the mother tongue and the level of perceived achieved communication apprehension in a foreign language.

Hypothesis 1.1. The higher the achieved communication apprehension in the mother tongue is, the higher it is in foreign languages.

Hypothesis 1.2. The lower the achieved communication apprehension in the mother tongue is, the lower it is in foreign languages.

\subsection{Methodology}

The hypothesis shall be verified by a combination of questionnaires - Levine [15], PRCA-24 [26]. The hypothesis shall be evaluated by a method of regression statistics, regression line, and correlation.

The last part of Levine questionnaire [15] focused on the investigation of communication apprehension. This part of the questionnaire dealt with scaling. Within 7 items, students expressed a level of their anxiety (apprehension) in using the 1st foreign language in teaching on a scale from $1=$ completely disagree to $5=$ completely agree with the statement.

The second type of a questionnaire was the PRCA-24 questionnaire (used, for example, in McCroskey's research [18]) focused on respondents' discovering a general level of communication apprehension in their mother tongue. The questionnaire contains 24 questions grouped into four meaning sub-areas (group discussion, meetings, interpersonal conversations, public speaking) of which each is characterized by 6 items. The questionnaire in a stated set of questions contains also items that were asking for identical or very close information which increases reliability of the entire questionnaire. In communication apprehension measurement, on Likert's scale ( $1=$ absolutely agree, $5=$ absolutely disagree $)$ respondents identified a level to what extent the sets of statements related to them.

The research was carried out at the Faculty of Social and Economic Studies of Jan Evangelista Purkyně University in Ústí nad Labem in seminars and classes of a professional foreign language. At the FSES UJEP the professional foreign language (English or German) is taught from the following fields: Economics and Management, Regional Development and Public 
Administration, Social Work. In all selected courses students expressed their opinion on their first, i.e. the main foreign language that they study at university in courses at which the level of students' language skills should achieve the $\mathrm{C} 1$ level according to the Common European Framework of Reference for Languages: i.e. the second highest level of language competence.

The basic research set was formed by all students of full-time bachelor's and subsequent master's degree of all study programmes and fields of study at the FSES UJEP in Ústí nad Labem. By a stratified selection, we chose a certain research sample from this basic set for the purpose of our investigation. The main criterion of this selection was teaching of the $1 \mathrm{st}$ foreign language currently in progress. The method of questionnaire survey addressed 328 students in total.

\subsection{Research Results}

\subsubsection{Level of Communication Apprehension in Foreign Languages}

While processing the data from Levin's questionnaire regarding the extent of student's communication apprehension in relation to their $1^{\text {st }}$ foreign language, we can proceed from the division of all 7 items to 2 thematic parts. The first part of the questionnaire (items 1-3) relates to the data about a general level of communication apprehension, about feelings resulting from subjective perception of foreign language communication in the 1st foreign language. The second part (items 4-7) describes communication apprehension with regard to a certain particular context, for example during a discussion about grammar, common topics, tests, and while discussing administrative issues. The values stated in Figure 1 represent average values of scalable answers.

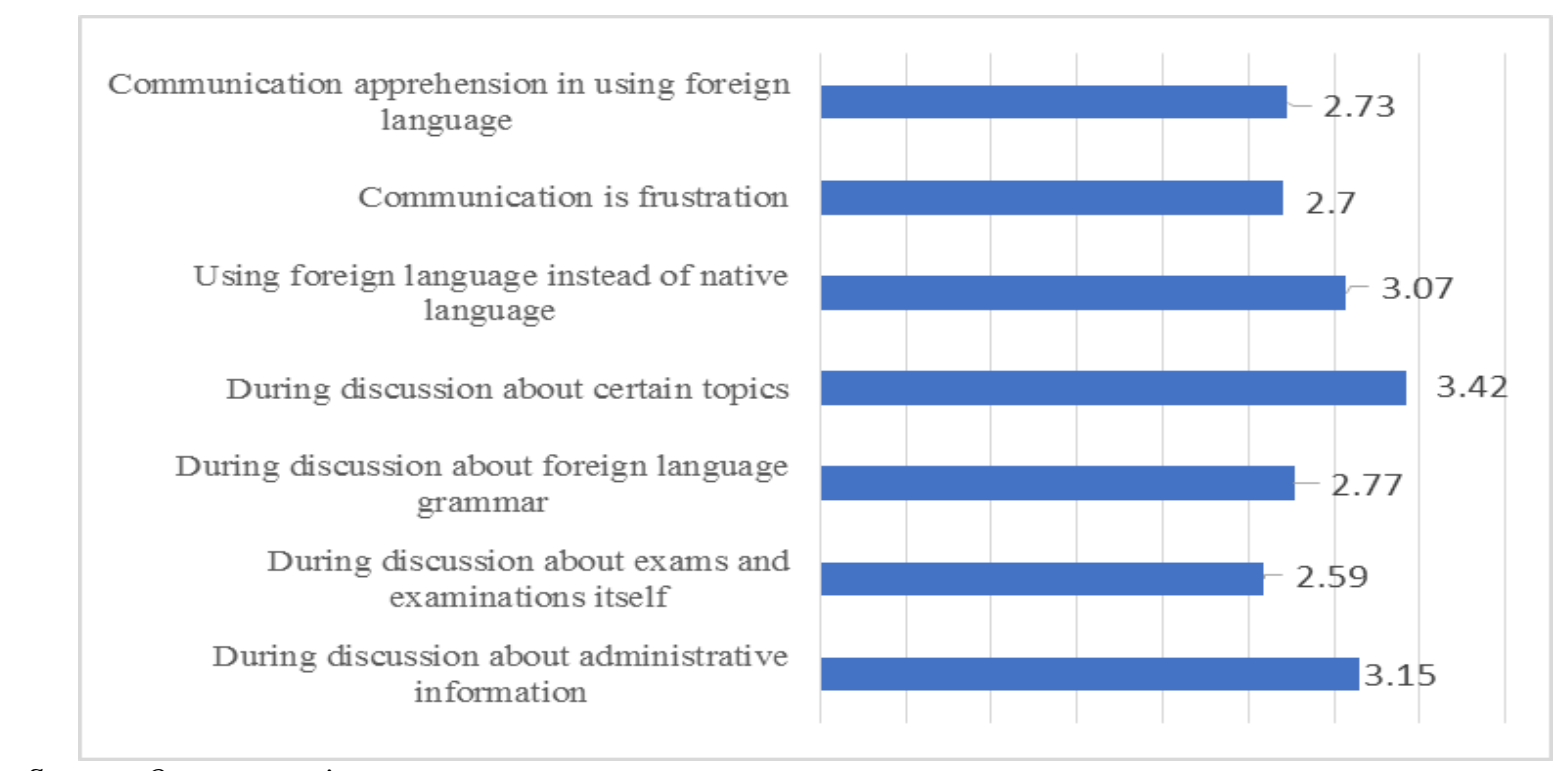

Source: Own processing

Fig. 1: The level of agreement with scalable answers about communication apprehension while using foreign language

The whole graph (Figure 1) shows in absolute and relative totals the frequency of answers that are related to communication apprehension. From this data it is obvious that students perceive communication within the 1st foreign language as a useful stimulus if they have to choose within communication between the foreign language and mother tongue $(x=3.06)$. At the same time they show a relatively high level of communication apprehension $(x=2.73-$ apprehension while using a foreign language $=$ communication within foreign languages is frustrating for them $x=2.70$ ). In terms of thematic context, the item titled "discussion about 
foreign language grammar and discussion about tests" mostly approaches the level of agreement always at the border between the scale of $2-3$. The students likely imagined grammar practice of the 1st foreign language which is not easy in any way because it is focused on its occurrence in a professional style.

A similar case is an item titled "anxiety during the discussion about tests, examination" which is certainly always a stressful situation for students regardless of the subject or a field; therefore more students stated their consent with this item.

Graphic representation (Figure 2) expressed as a percentage level of agreement with a given statement almost overlaps in both cases. Based on percentage expression of these two answers, communication apprehension in foreign languages forms almost $20 \%$, that is approximately $1 / 5$ of respondents. If we add up the limit values of both statement types (level $1+2$, level 4+5) and compare them, we can find out that the level of disagreement with the given statement exceeds the level of agreement, therefore, there are more students (approx. by 1/4) who do not feel any apprehension in foreign languages. These are the students who, on the contrary, express a positive variant of the examined phenomenon and willingness to communicate.

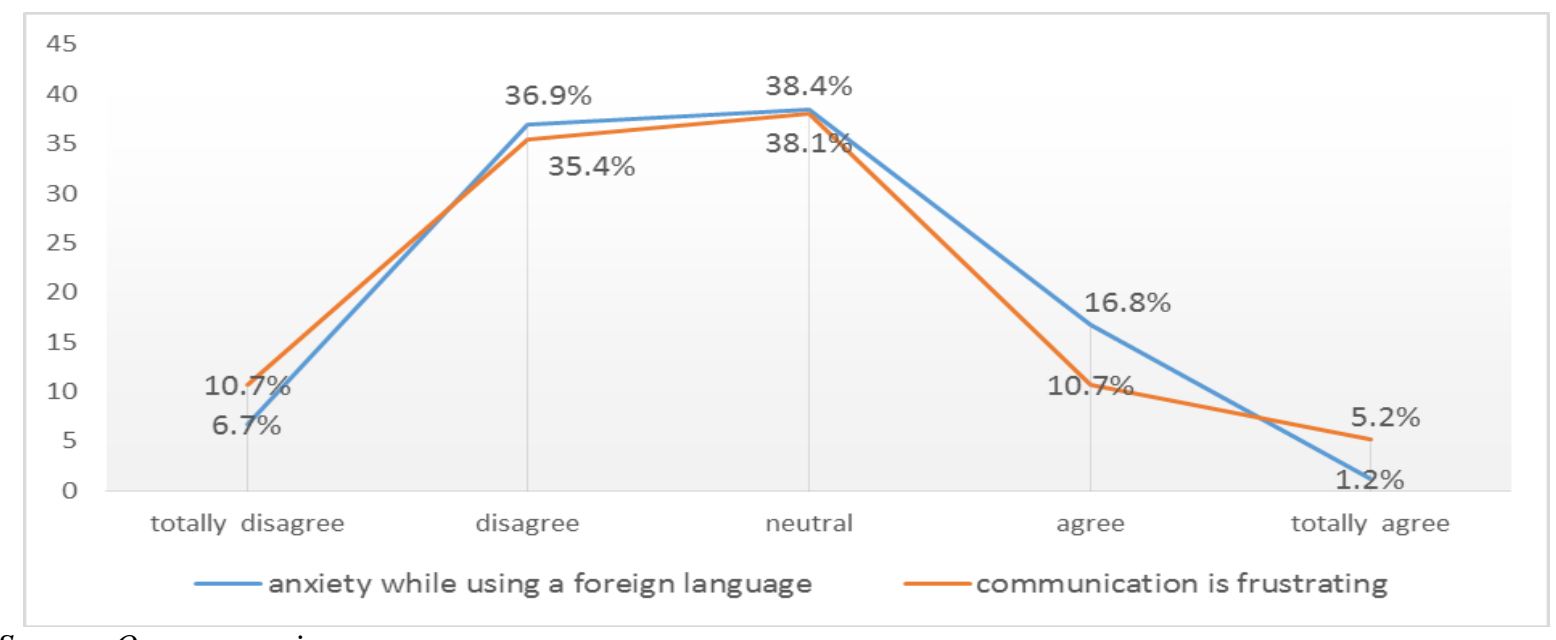

Source: Own processing

Fig. 2: Graphic representation of the level of agreement with communication apprehension

If, at all 7 items stated in Figure 1, we add up the limit values of the percentage expression of disagreements (values 1+2) and limit values of agreement expression with the given statement (values $4+5$ ) with maintaining the middle, neutral value 3 , and create an average percentage expression of these values, we can find out (Figure 3 ) that almost $46 \%$ of students admit a low level of communication apprehension in foreign languages, 37\% admit a medium level, and $17 \%$ of respondents experience a high level of communication apprehension in foreign languages. 


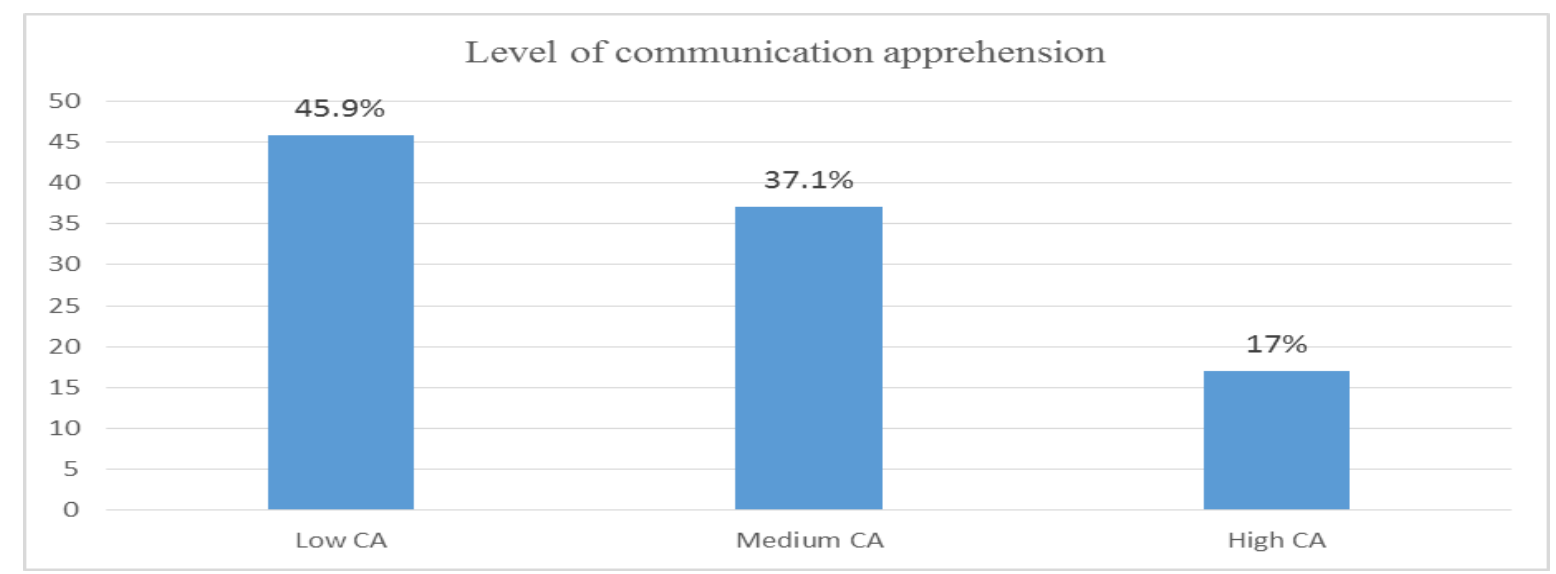

Source: Own processing

Fig. 3: Total percentage statement of the level of communication apprehension in foreign languages

Since the character of all items in the questionnaire was identical, from the lowest level of communication apprehension to the highest level, we performed a simple sum of all values at individual items and we continued working only with this sum. The total lowest value of communication apprehension in students was expressed by the lowest sum of values of all seven items and reached 7 points; the highest level of communication apprehension was 35 points. In our survey, nobody reached the 7-point limit, the lowest value recorded was 8 points (at 1 respondent); the highest value was 33 points (also in 1 case). Thus the limit values did not occur at all in our survey. The total stratification of recorded values that we divided into 5 categories according to incidence is shown in the Table 1 table and graphic representation, Figure 4.

Tab. 1: Frequency of sum of recorded values

\begin{tabular}{|l|c|c|c|c|c|}
\hline Interval values & $\mathbf{7 - 1 0}$ & $\mathbf{1 1 - 1 5}$ & $\mathbf{1 6 - 2 0}$ & $\mathbf{2 1 - 2 5}$ & $\mathbf{2 6}-$ \\
\hline Number of cases & 35 & 88 & 121 & 53 & 31 \\
\hline
\end{tabular}

Source: Own processing

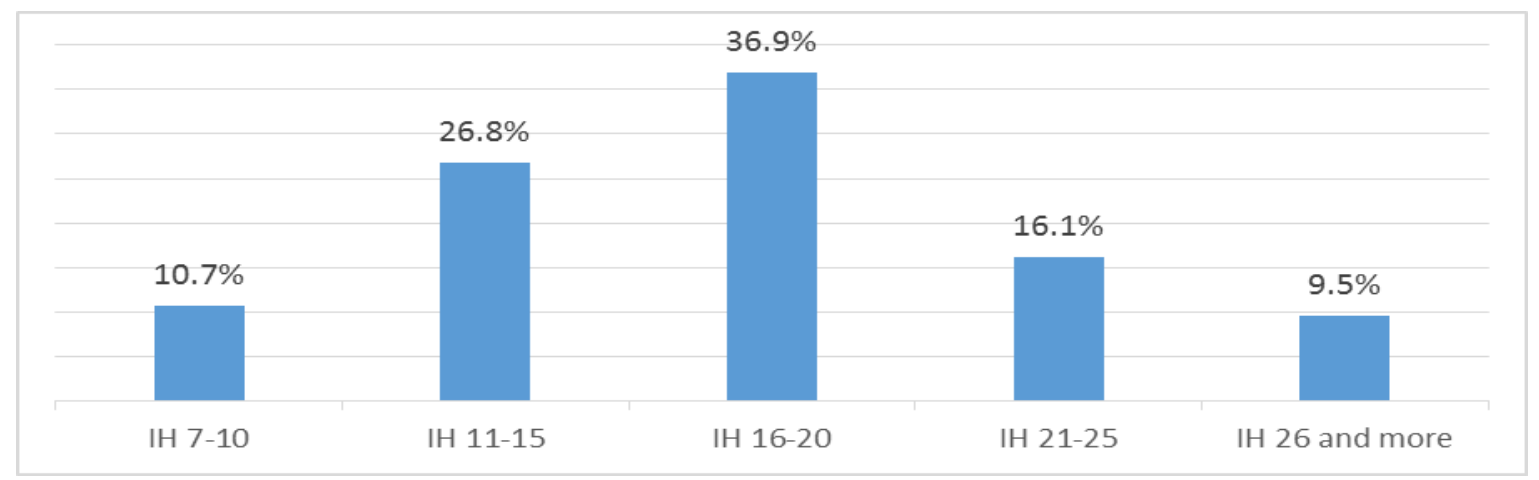

Source: Own processing

Fig. 4: Frequency of sum of recorded values - percentage statement (IH = interval values $)$

It is obvious from the quantities stated in Table 1 and Figure 4 that the limit values (in our case the values up to 10 and above 26 formed by summation) occur in the lowest rate, on the contrary the medium value (121 cases in total) was recorded the most. The number of cases with a particular categorical expression increases exponentially up to this medium value, and then it sharply decreases. It follows from Figure 4 that the lowest level of communication apprehension (value 1) was chosen by at least 35 students in their responses to individual items, a similar number - 31 students (the sum of whose values is 26 and above, therefore at 
least the second highest level of communication apprehension - level 4 - must have been used here) mostly chose the level 5 to express their response, therefore the level of the highest communication apprehension.

The total sum of values above 30 was recorded in 7 cases, out of these $3 \times$ value $31,3 \times$ value 32, and $1 \times$ value 33. In these cases the highest value (i.e. 5) was used in most cases (at least 3 times; 4 and 5 times in other cases) to express the highest level of communication apprehension in foreign languages.

We supposed that the most frequently recorded value formed by the sum of values from individual items would be the value 21 formed by a simple sum of medium values, i.e. in most cases the students will not be able to describe, numerically expressed respectively, the extent of their subjectively perceived communication apprehension, thus they will choose an average value which can, except for the average extent, express also a certain indecisive opinion or an "I don't know" response. This value was recorded in 28 cases in total but another value occurred in the survey in a much higher extent. The value 19 (i.e. the total sum of chosen $1-5$ values) was recorded in 34 cases in total.

\subsubsection{Level of Communication Apprehension in Mother Tongue}

The PRCA-24 questionnaire was divided into 4 sub-categories and each of these was characterized by 6 items. By assigning a score to all 24 items grouped to 4 sub-categories and by adding up this score it was possible to reach values between 6 and 30 points. Nobody reached the limit values 6-8 (almost a zero level of communication apprehension); the lowest level recorded in our survey was 9. At the same time, nobody reached the highest possible level, that means 30 points, to express a very high communication apprehension at individual sub-categories (the highest level recorded in our survey was 28). We added up the score of individual sub-categories, see Table 2. The lowest score recorded in our survey was 39, the highest score was 104. The score between 24 and 55 point indicated a low level of communication apprehension, the score within 56-83 points indicated a medium level of communication apprehension, and the score from 84 to 120 points expressed a high level of communication apprehension.

We can state that communication apprehension in observed students most frequently reaches the medium, i.e. the average value, but the second highest number of recorded cases lies within the category of high communication apprehension in mother tongue. Only almost $10 \%$ of respondents (24 in total, i.e. 7.3\%) show a low or very low level of communication apprehension in mother tongue.

Tab. 2: Achieved level of communication apprehension in native language

\begin{tabular}{|l|c|c|c|}
\hline Communication apprehension & Low & Medium & High \\
\cline { 2 - 4 } & $24-55$ points & $56-83$ points & $84-120$ points \\
\hline Total number of respondents $N=328$ & 24 respondents & 214 respondents & 90 respondents \\
\hline
\end{tabular}

Source: Own processing 


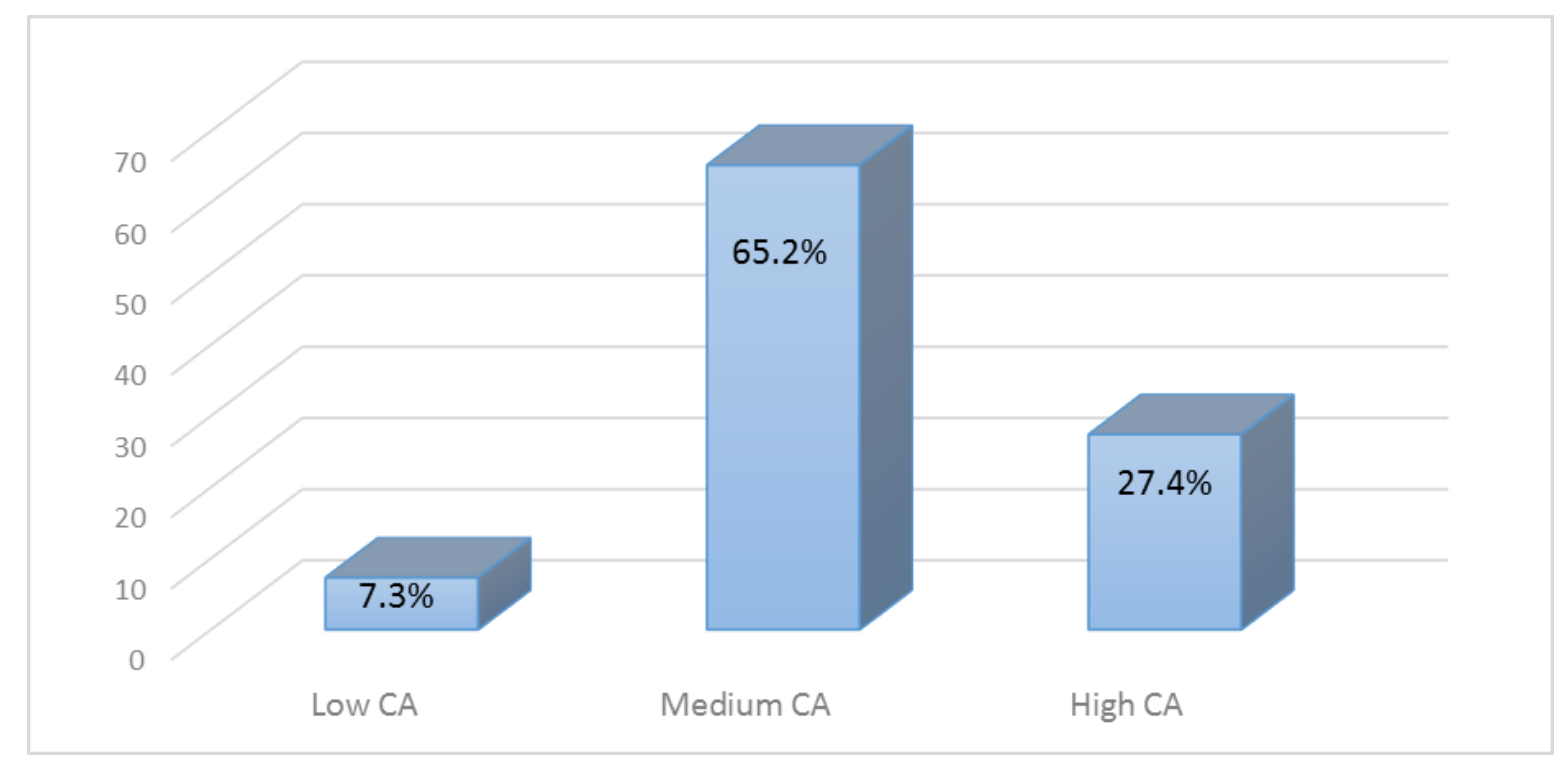

Source: Own processing

Fig. 5: Graphic expression of achieved communication apprehension in native language

If we compare Figure 5 above with a graphic representation of the total average communication apprehension in foreign languages (Figure 3) we can find out that students admit their communication apprehension in mother tongue more often than in a foreign language (Figure 6).

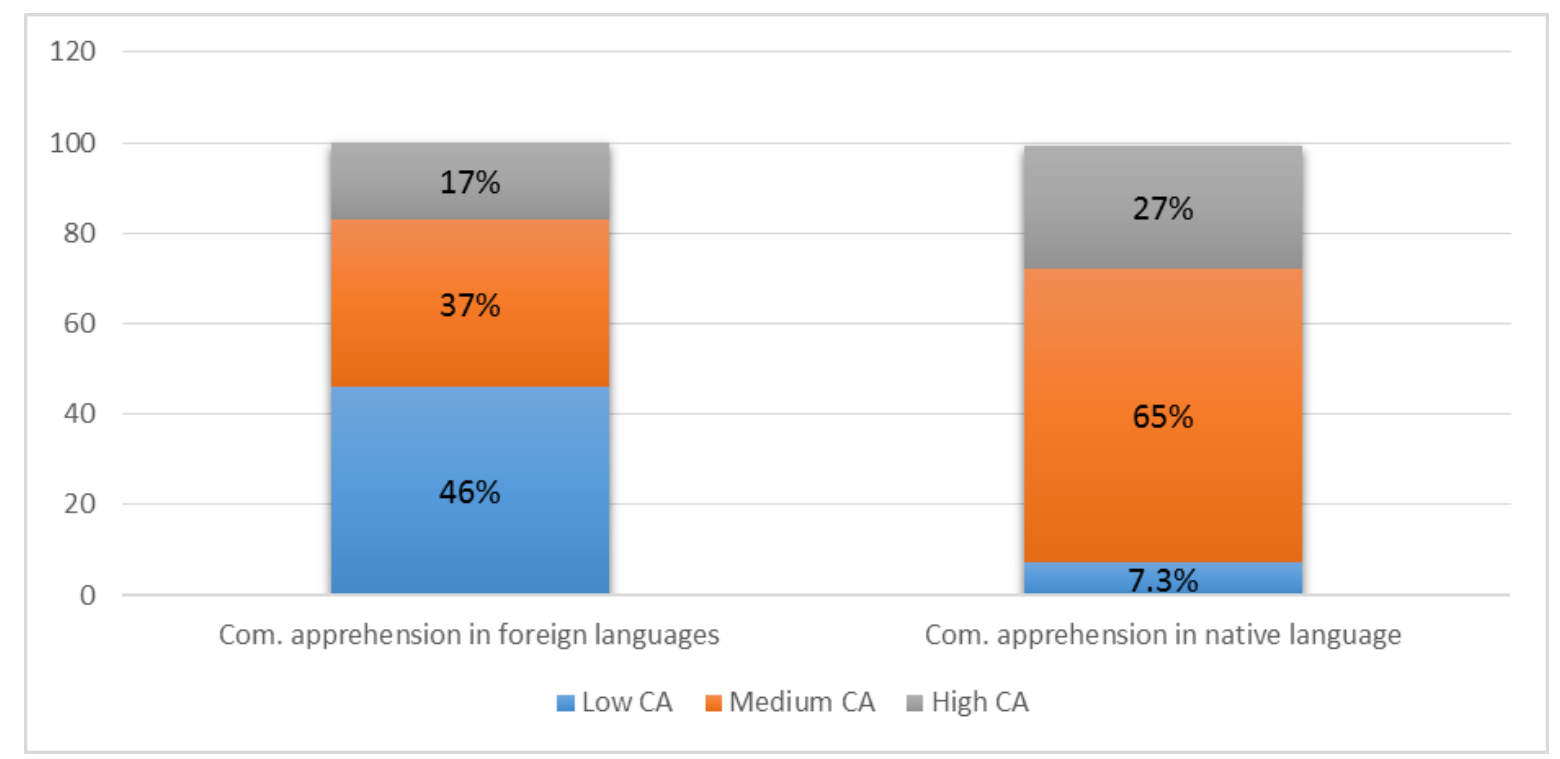

Source: Own processing

Fig. 6: Comparison of the levels of communication apprehension in native language and in foreign languages

\subsection{Evaluation of Data Related to Hypotheses}

At the beginning we formulated a null hypothesis speaking about mutual dependency of both observed variables. We developed contingency tables and determined the level of significance $\alpha=0.05$. By using the statistical program Statistica we found out the value of the $R$ correlation coefficient. 
Source: Own processing

\begin{tabular}{|l|c|}
\hline \multicolumn{2}{|c|}{ Regression statistics } \\
\hline Multiple $R$ & 0.619816 \\
\hline Index of determination & 0.384171 \\
\hline Value of reliability $R$ & 0.382282 \\
\hline Standard Error & 4.300232 \\
\hline Number of observations & 328 \\
\hline
\end{tabular}

Based on the model of regression line we found out the determination index which, with a value of $38 \%$, showed only a medium-strong linear dependency (high scattering even out of the line area) but the discovered p-value was lower than 0.05 and the value of Spearman's $R$ correlation coefficient was higher than 0.05 (Table 3 ) as a determined level of significance $(0.619>0.05)$, thus we rejected the null hypothesis about independency of both variables and we consider the existence of dependency among the observed signs proven. This conclusion also emphasizes out interpretations of graphic representation (Figure 7) of the regression line which shows the upward tendency.

The important value is the determination index which is also related to the below mentioned graphic representation. The line model explains the data variability from approximately $38 \%$ (i.e. $38 \%$ of the total variability of the dependent variable explained by the model), that means that in our case it is a medium-strong linear dependency. The graphic representation obviously shows the tendency indication, the upward tendency of the points scored of both variables, that is apprehension in foreign languages is dependent on apprehension in mother tongue and vice versa. However, it is not a linear line (it was the $100 \%$ dependency) but only $38 \%$ dependency expression, high variability.

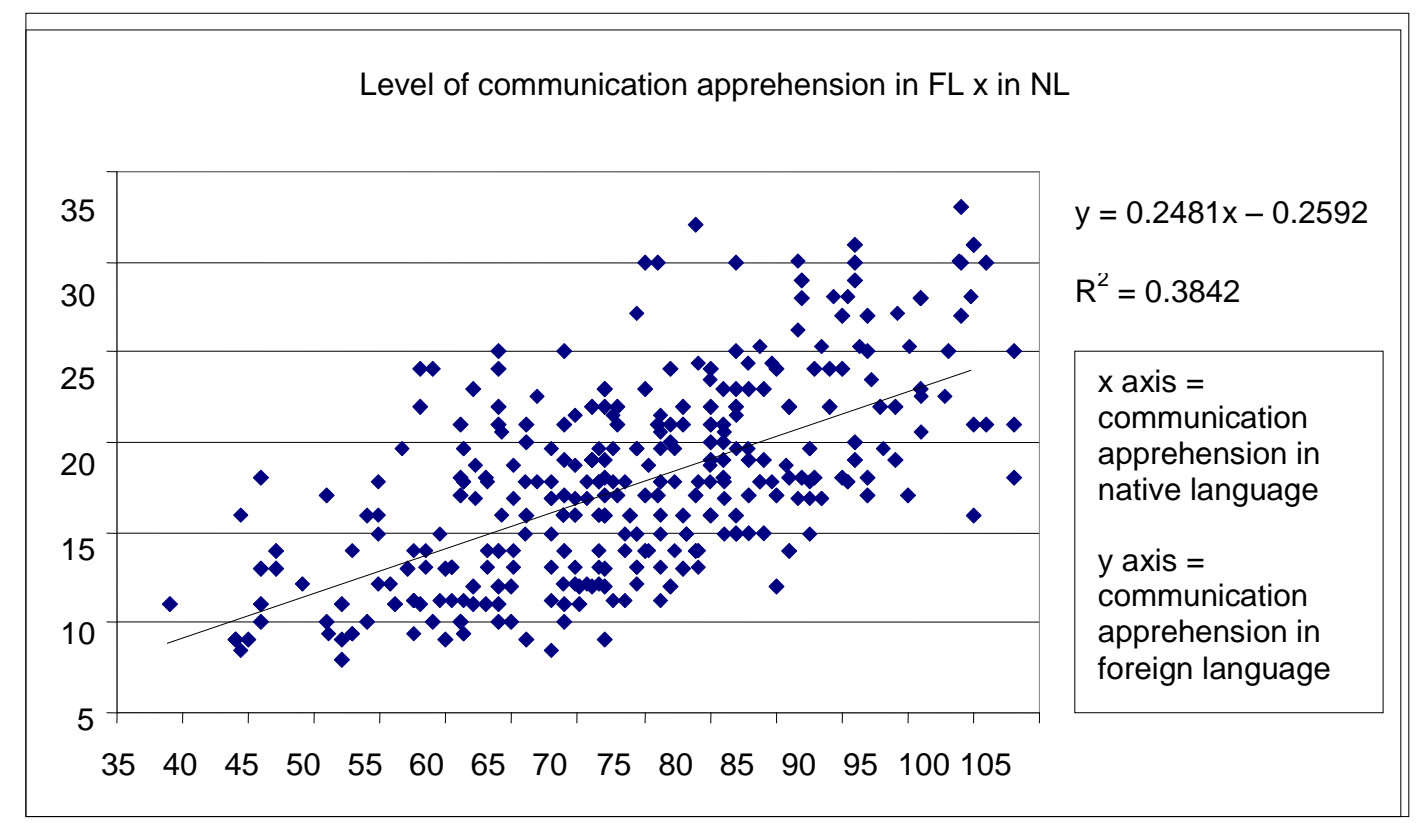

Source: Own processing

Fig. 7: Regression line

The incline direction of the regression line is positive and its value is almost 0.25 , i.e. it means that when communication apprehension in mother tongue increases by 1 point, the average increase of communication apprehension in foreign languages is by 0.25 point, i.e. by $1 / 4$. Figure 7 clearly shows that there is no linear dependency of both variables because the point do not lie directly on the line (i.e.it does not apply here that if $\mathrm{x}$ is low, then $\mathrm{y}$ is low too) but 
they are scattered throughout the entire area delimited by $\mathrm{x}$ and $\mathrm{y}$ axes. However, the indication of the upward tendency, i.e. $\mathrm{y}$ grows with growing $x$, is obvious here. The calculated $p$-value (Table 4 ) is almost zero, $p=3.4 \mathrm{E}-36$, i.e. it is an important model but not very accurate in connection to the already mentioned determination index which records only $38 \%$ data variability.

Due to the fact that the total significance is almost zero, we can state that despite the measured value of the determination index we rejected the null hypothesis on independency. Therefore, we can state that the relation between the level of communication apprehension in foreign languages and the level of communication apprehension in mother tongue was confirmed. The hypothesis consisting of sub-hypotheses 1.1 and 1.2 was also confirmed. Therefore, it applies that there is a mutual relation (direct proportion) between the level of perceived achieved communication apprehension in mother tongue and the level of perceived achieved communication apprehension in mother tongue.

Tab. 4: Statistical hypothesis data

\begin{tabular}{|l|l|l|l|l|l|}
\hline & Difference & SS & MS & F & Signification $\boldsymbol{F}$ \\
\hline Regression & 1 & 3760.68 & 3760.68 & 203.3679919 & 3.40883 E-36 \\
\cline { 1 - 5 } Residues & 326 & 6028.39 & 18.49199 & & \\
\cline { 1 - 4 } Total & 327 & 9789.07 & \multicolumn{3}{|l}{} \\
\cline { 1 - 3 }
\end{tabular}

\begin{tabular}{|l|c|c|c|c|c|c|c|c|}
\hline & Coefficients & St. Error & $\boldsymbol{t}$ stat & P Value & Lower 95\% & Upper 95\% & Lower 95\% & Upper 95\% \\
\hline Limits & -0.2592 & 1.3302 & -0.1949 & 0.8456 & -2.876 & 2.3576 & -2.876 & 2.3576 \\
\hline File X 1 & 0.2481 & 0.0173 & 14.261 & $3.40 \mathrm{E}-36$ & 0.214 & 0.282 & 0.213 & 0.282 \\
\hline
\end{tabular}

Source: Own processing

\section{Conclusion}

As already stated, the Hypothesis 1 is confirmed by the $p$-value but the determination index and graphic representation of both variables show only the medium-strong linear dependency. It means that a certain proportion of respondents have a subjectively perceived level of communication apprehension in a foreign language and in their mother tongue at approximately the same level. If they are not shy to communicate in their mother tongue, they usually do not hesitate to communicate in a foreign language. And vice versa, higher communication apprehension in foreign languages is represented by those who also have a high value of communication apprehension in their mother tongue. Therefore, they are uncommunicative in both (and perhaps also other) languages and can be assigned to uncommunicative types while the first ones can be assigned to communicative types.

There is also a high percentage of those to whom this linear dependency (direct proportion) does not apply. In these are students we can observe rather a mutual inverse proportion of both variables. Students who have low communication apprehension in their mother tongue but show communication apprehension in foreign language education and state a high value of communication apprehension in their 1st studied foreign language. On the other hand, there are also students who do not tend to communicate in their mother tongue so much, we record a high level of communication apprehension in them, while in foreign languages this apprehension in mother tongue was not so evident, and was not transferred. On the contrary, we perceive here a medium or low level of communication apprehension in foreign languages. These are all cases stated in Figure 7 under the indicated line in the right area of the chart.

It followed from the mutual correlation of communication apprehension in foreign languages and in mother tongue that these two variables are mutually dependent. Our hypothesis was 
confirmed, although not convincingly. We assumed insignificant correlation here. In case of communication apprehension in mother tongue, it is then caused by other influences and has a different character than communication apprehension in a foreign language. A family as the basic attribute of maternal communication plays a more important role here than in communication apprehension in a foreign language.

We know that stress and fear may create extremely formidable barriers in foreign language acquisition. It is, therefore, important, as stated by Průcha [23] based on the research of American experts Gibb and Rosenfeld, to create a supportive (i.e. encouraging, helpful) communication climate in which the participants mutually respect each other and in which they participate. In other words, this communication climate is to evoke mutual communication of students when they completely openly, clearly and without concerns express their opinions and feelings. The mentioned climate has also a crucial influence on students' motivation and their attitude to learning as emphasized also by our leading expert on lingvodidactics, Hendrich, who in [7] puts emphasis on pedagogical-psychological diplomacy of a teacher and on his/her ability to create "a climate of mutual understanding and cooperation in the process of foreign language acquisition".

\section{Acknowledgements}

The research is financed by the internal grant agency of the J. E. Purkyně University in Ústí nad Labem in the Czech Republic.

\section{Literature}

[1] CELEROVÁ, J. Komunikační bariéry a jejich odstraňování v podmínkách smíšeného jazykového a kulturního prostředí studentů PF UJEP. Sborník vědeckých prací Univerzity Pardubice. Pardubice: 2006. pp. 33-38, ISBN 80-7194-893-4.

[2] COMADENA, M. E.; PRUSANK, D. T.: Communication apprehension and academic achievement among elementary and middle school students. Communication Education. 1988, Vol. 37, Issue 4, pp. 270-277. DOI: $10.1080 / 03634528809378728$

[3] CRAWFORD, J.: Language Choices in the Foreign Language Classroom: Target Language or the Learners' First Language? RELC Journal. 2004, Vol. 35, Issue 1. ISSN 0033-6882. DOI: $\underline{10.1177 / 003368820403500103}$

[4] DUFF, P. A.; POLIO, Ch. G.: Teachers Language Use in University Foreign Language Alternation. The Modern Language Journal. 1994, Vol. 78, Issue 3, pp. 313-326. DOI: $10.1111 / \mathrm{j} .1540-4781.1994 . t b 02045 . \mathrm{x}$

[5] FORSTER, R. Entwicklung der mündlichen Kommunikationsfähigkeit im Fach Deutsch in den baltischen Staaten. Zielsprache Deutsch. 1999, Vol. 30, Issue 1, pp. 28 33. ISSN 0341-5864.

[6] GARDNER, R. C.; MacINTYRE, P. D.: On the Measurement of Affective Variables in Second Language Learning. Language Learning. 1993, Vol. 43, Issue 2, pp. 157-194. DOI: $10.1111 / \mathrm{j} .1467-1770.1992 . t b 00714 . \mathrm{x}$

[7] HENDRICH, J. a kol. Didaktika cizích jazyků. Učebnice pro vysoké školy. 1. vydání. Praha, SPN, 1988.

[8] HORWITZ, E.: Language Anxiety: From Theory and Research to Classroom Implications. Engelwood Cliffs. Prentice Hall, 1991. 
[9] HUTCHINSON, K. L.; NEULIEP, J. W.: The influence of parent and peer modeling on the development of communication apprehension in elementary school children. Communication Quarterly. 1993, Vol. 41, Issue 1, pp. 16-25. DOI: $10.1080 / 01463379309369864$

[10] CHODĚRA, R. a kol.: Výuka cizich jazyků na prahu nového století II. 1. vydání. Ostrava: Ostravská univerzita, 2000. 166 pp. ISBN 80-7042-157-6.

[11] JELÍNEK, S.: K některým otázkám bilingvismu (II). Cizi jazyky. 2005/2006, Vol. 49, Issue 1. pp. 8-10.

[12] KLAPPER, J.; COLEMAN, J. A.: Effective Learning and Teaching in Modern Languages. Routledge, 2005. ISBN 0415346649.

[13] KRASHEN, S.: The Natural Approach. London, Prentice-Hall International, 1982. ISBN 0-13-612029-6.

[14] Ǩ̌IVOHLAVÝ, J.: Komunikace učitelů se žáky. Olomouc, Český pedagogický ústav, 1987.

[15] LEVINE, G. S.: Student and Instructor Beliefs and Attitudes about Target Language Use, First Language Use, and Anxiety: Report of a Questionnaire Study. The Modern Language Journal. 2003, Vol. 87, Issue 3, pp. 343-364. ISSN 0026-7902. DOI: $10.1111 / 1540-4781.00194$

[16] MACARO, E.: Teacher use of codeswitching in the second language classrooms: exploring 'optimal' use. In: M. Turnbull; J. Dailey-O'Cain (eds.), First Language use in Second and Foreign Language Learning. Bristol, Multilingual Matters, 2009.

[17] MAREŠ, J.; KŘIVOHLAVÝ, J.: Komunikace ve škole. 1. vydání. Brno, Masarykova univerzita, 1995. ISBN 80-210-1070-3.

[18] McCROSKEY, J. C. The Communication Apprehension Perspective. In: J. A. Daly; J. C. McCroskey (eds.), Avoiding communication: Shyness, reticence, and communication. Beverly Hills, CA: SAGE Publications, 1984. pp. 13-38.

[19] McCROSKEY, J. C.; RICHMOND, V. P.; WRENCH, J. S.: Communication Apprehension, Avoidance, and Effectiveness. Needham Heights, MA, Allyn and Bacon, 1998.

[20] OXFORD, R. L.: Cooperative Learning, Collaborative Learning, and Interaction: Three Communicative Strands in the Language Classroom. The Modern Language Journal. 1997, Vol. 81, Issue 4, pp.443-456. DOI: 10.1111/j.1540-4781.1997.tb05510.x

[21] POKORNÝ, J. Psychologie tvořivého myšlení. Učebni texty vysokých škol. Brno: VUT, 2002, 102 pp. ISBN 80-214-2065-0.

[22] PRŮCHA, J.: Alternativni školy a inovace ve vzdělávání. 1. vydání. Praha: Portál, 2001, 144 pp. ISBN 80-7178-584-9.

[23] PRŮCHA, J.: Moderní pedagogika. Praha: Portál, 1997.

[24] PRŮCHA, J.; WALTEROVÁ, E.; MAREŠ, J.: Pedagogický slovník. Praha, Portál, 1995, 292 pp. ISBN 80-7178-029-4.

[25] PRŮCHA, J.: Přehled pedagogiky: Úvod do studia oboru. 1. vydání. Praha, Portál, 2000. 272 pp. ISBN 80-7178-399-4. 
[26] SOlOMON, D. H.; KNOBLOCH, L. K.: Communication Arts 100 Study. The Impact of Communication Arts 100: Introduction to Speech Composition on Communication, Writing and Library Anxiety. 1/2000.

[27] STERNBERG, R. J.: Kognitivni psychologie. Praha: Portál, 2009. ISBN 978-80-7367638-4.

[28] VYBÍRAL, Z.: Psychologie lidské komunikace. 1. vydání. Praha: Portál, 2000, 264 pp. ISBN 80-7178-291-2.

[29] YOUNG, D. J.: An investigation of students' perspectives on anxiety and speaking. Foreign Language Annals. 1990, Vol. 23, Issue 6, pp. 539-553.

PhDr. Bc. Kateřina Smejkalová, Ph.D.; PhDr. Ing. Josef Smejkal, Ph.D. et Ph.D.;

Bc. Kateřina Juráčková 


\section{VLIV KOMUNIKAČNÍ OSTÝCHAVOSTI NA PROCES OSVOJOVÁNÍ CIZÍHO JAZYKA}

Cílem tohoto př́spěvku je zaměřit se na jev, který dosud v české odborné literatuře nebyl výrazně zkoumán, a to na tzv. komunikační ostýchavost. Po vymezení odborné terminologie je hlavní část článku zaměřena na analýzu výzkumného šetření zkoumajícího studenty percipovanou úroveň komunikační ostýchavosti. V souvislosti s výzkumnými závěry i se zkušenostmi z výuky, kdy studenti při cizojazyčné výuce na vysokých školách vykazují vyšší míru pasivity, neochotu komunikovat a komunikační ostýchavosti, bude v empirické části této práce položena též otázka, zda existuje vztah mezi studenty vnímanou úrovní komunikační ostýchavosti v cizím a v mateřském jazyce.

\section{AUSWIRKUNGEN DER SPRACHVERWENDUNGSANGST AUF DEN PROZESS DES SPRACHENLERNENS}

Ziel dieses Beitrags ist es, sich an das Ereignis zu konzentrieren, welches bislang in der tschechischen Fachliteratur nicht hinreichend untersucht wurde, und zwar die sogenannte Sprachverwendungsangst. Nach der Festlegung der fachspezifischen Terminologie richtet sich der Hauptteil des Artikels auf die Analyse der Forschung, die sich auf die von den Studenten perzipierte Ebene der Sprachverwendungsangst konzentrierte. Im Zusammenhang mit den Ergebnissen der Forschung sowie mit den Erfahrungen aus dem Unterricht, in dem die Studenten bei der Fremdsprachenausbildung an den Hochschulen ein höheres Maß an Passivität, Kommunikationsunwilligkeit und Sprachverwendungsangst ausweisen, wird im empirischen Teil dieser Arbeit auch die Frage gestellt, ob eine Beziehung zwischen der von den Studenten wahrgenommenen Ebene der Sprachverwendungsangst sowohl in der Fremdsprache als auch in ihrer Muttersprache besteht.

\section{WPŁYW NIEŚMIAŁOŚĆI KOMUNIKACYJNEJ NA PROCES PRZYSWAJANIA JĘZYKA OBCEGO}

Celem niniejszego artykułu jest zwrócenie uwagi na zjawisko, które do tej pory nie było badane w literaturze czeskiej, na tak zwaną nieśmiałość komunikacyjną. Po zdefiniowaniu terminologii specjalistycznej główna część artykułu koncentruje się na analizie badań, która bada postrzegany przez studentów poziom nieśmiałości komunikacyjnej. W związku z wynikami badań i doświadczeniami z dydaktyki wskazującymi, że studenci podczas nauki języków obcych na uczelniach wykazują wyższy stopień bierności, niechęci do komunikowania się i nieśmiałości komunikacyjnej, w empirycznej części tego opracowania postawione zostanie pytanie, czy istnieje związek między postrzeganym przez studentów poziomem nieśmiałości komunikowania się w języku obcym i w języku ojczystym. 